\title{
Transfacial Approach, Pedicled Rhinotomy for a Clival Chordoma: A Technical Report
}

\author{
Klivus Kordoması için Pediküllü Rinotomi ile Transfasial Yaklaşım: \\ Teknik Bildiri, Olgu Sunumu
}

\author{
Ahmet Murat MUSLUMAN ${ }^{1}$, Adem YILMAZ ${ }^{1}$, Ibrahim COLAK ${ }^{1}$, Halit CAVUSOGLU ${ }^{1}$, Kemal UGURLU², \\ Yunus AYDIN ${ }^{1}$ \\ ${ }^{1}$ Sisli Etfal Education and Research Hospital, Department of Neurosurgery, Istanbul, Turkey \\ ${ }^{2}$ Sisli Etfal Education and Research Hospital, Department of Plastic and Reconstructive Surgery, Istanbul, Turkey
}

Correspondence address: Ahmet Murat MUSLUMAN / E-mail: mmusluman@yahoo.com

\begin{abstract}
Clival chordomas are frequently midline structures. Due to their critical location, invasive nature and aggressive recurrences, skull base chordomas are difficult to manage surgically. We present a case operated on with the pedicled transnasal and transfacial approach. The case presented with neurological deficits as cranial nerve palsy and findings of brainstem compression. The lesion was removed without any neurological deficit. Her deficits related to brainstem compression regressed after surgery. In our case, a large exposure was achieved through a lateral nasal incision in order to excise the tumor totally with acceptable cosmetic results, and a successful outcome was observed during the postoperative follow-up period with the surgical procedure applied.
\end{abstract}

KEYWORDS: Rhinotomy, Chordomas, Clivus, Skull base tumor

öz

Klivus kordomaları sıklıkla orta hat lezyonlarıdır. Kafa tabanı kordomalarının kritik lokalizasyonu, invaziv yapısı ve sık nüks eden lezyonlar olması nedeniyle cerrahi tedavileri zorlayıcıdır. Bu bildiride pediküllü transnazal, transfasial yaklaşımla ameliyat edilen bir olgu sunuldu. Olgu kranial sinir paralizisi ve beyin sapı bası bulguları ile başvurdu. Lezyon herhangi bir nörolojik defisit olmaksızın çıkarıldı. Ameliyattan sonra olgunun beyin sapı bası bulguları geriledi. Olgumuzda lateral nazal insizyonla geniş bir cerrahi alan sağlanarak total tümör eksizyonu ile beraber kozmetik olarak da kabul edilir bir sonuç alınmıştır ve postoperatif takibinde uygulanan cerrahi prosedürün başarılı olduğu görülmüştür.

ANAHTAR SÖZCÜKLER: Rinotomi, Kordoma, Klivus, Kafa tabanı tümörü

\section{INTRODUCTION}

Numerous approaches have been described in the literature for the management of clival tumors. The technique to be applied is determined according to the location and size of the tumor (1). In a case with a chordoma localized in the upper middle clivus, we present our choice of pedicled transnasal and transfacial approach. This technique is a modification of the classical Weber-Ferguson incision. This approach involves the steps of right side nasal skin incision, nasal osteotomies, rotation of the left facial region of nose, removal of nasal septum, opening of ethmoidal and sphenoidal sinuses, and dissection of the pharynx for clival exposure.

There has been no published report on removal with modified pedicled rhinotomy for a clival chordoma in the literature.

\section{CASE REPORT and SURGICAL TECHNIQUE}

A forty-year-old female with complaints of headache, diplopia and drop attacks for 4 months was referred to our hospital. Neurological examination revealed sixth cranial nerve palsy (limitation of the lateral mobility of the left eye) and upper extremity numbness and tingling. Magnetic resonance imaging (MRI) showed a heterogenously contrasted mass lesion localized at the upper middle clivus destructing the sellar cavity and compressing the brainstem slightly which could be potentially consistent with chordoma (Figure 1A). The patient was underwent pedicled rhinotomy. The patient was supine with her head elevated at 15-20 degrees and intubated orally. Arterial blood flow (ABF) of the left facial artery was controlled with Doppler ultrasonography (USG), and was found to be satisfactory. Since fat or fascial graft might be required, the left inguinal and abdominal region were included in the surgical field. After surgical cleansing of the head and neck regions, nasal and oral cavities were again cleaned meticulously. The hypopharynx was packed with a tampon. The incision was started from the nasofacial line on the lateral margin of the right nasal wing. Inferiorly, the right nasal wing and columella were incised and the incision was advanced to the left nasal wing. Superiorly, the nasofacial incision was advanced horizontally from the frontonasal 

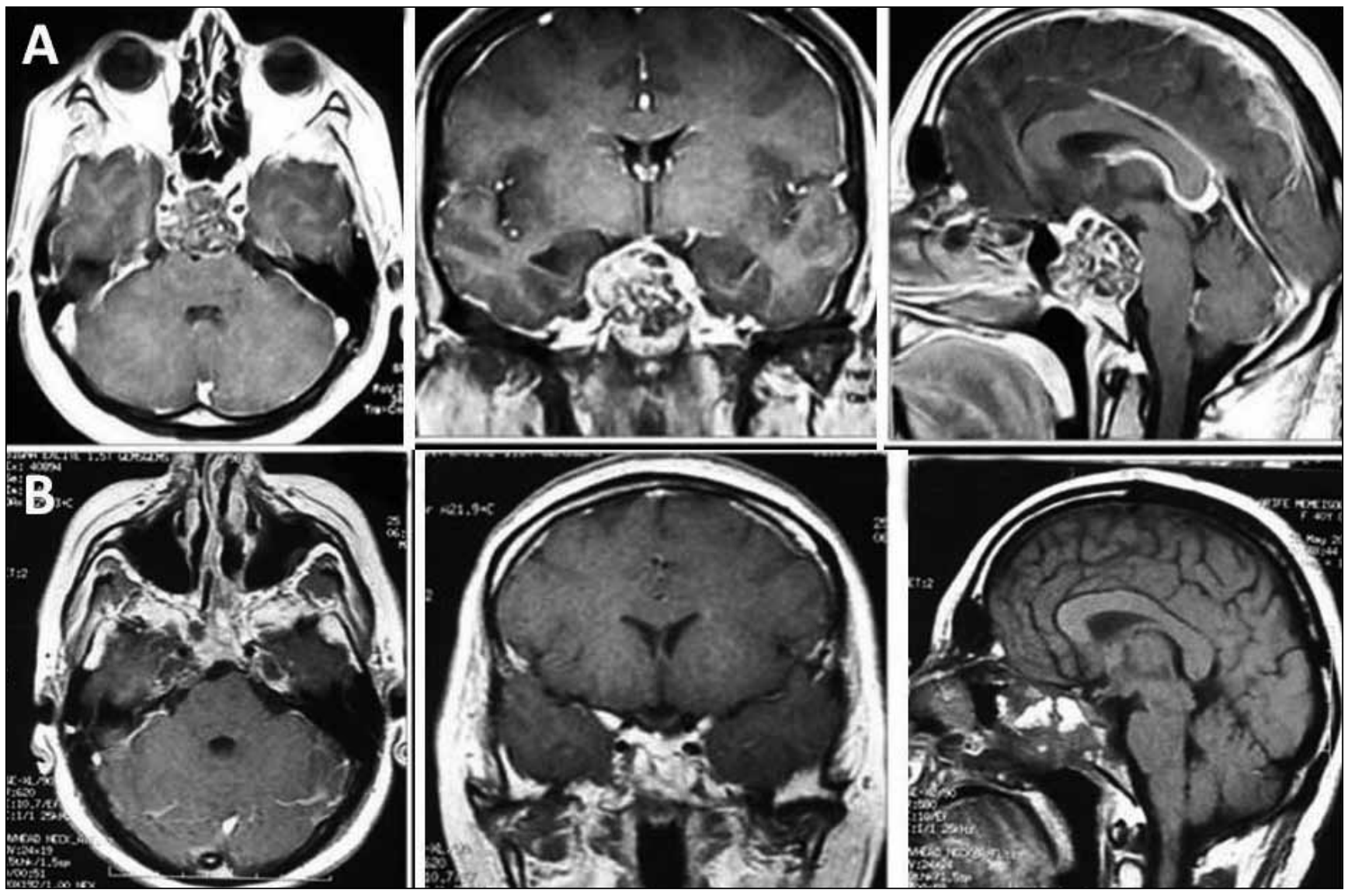

Figure 1: Preoperative and postoperative Cranial MR Images. A) Preoperative images: Axial/coronal/sagittal contrasted sections. a heterogenously contrasted mass lesion localized at the upper midclivus destructing the sellar cavity and compressing the brainstem, B) Postoperative Images: Axial/coronal contrasted, and sagittal non-contrasted sections: tumor was removed totally and fat graft is seen inside the loge.

commissure towards the contralateral nasal root. The incision was extended laterally to the bone, and the periosteum was elevated within a limited area. The nasal bone was dissected away from its mucosa medially, and osteotomized from the maxillary bone. For the left-sided nasal bone osteotomy, deep structures were entered through a small incision on the inferior tip at the level of apertura piriformis. The bone was deperiosted from the lateral and medial aspect. Superiorly, the frontonasal commissure was osteotomized to free all the nasal bones en bloc. The mucosa of the quadrangular cartilage was dissected and the cartilage was separated from the vomer. The nose was deviated leftward taking care not to injure the nasofacial arterial pedicle. The septal segment of the bone was resected together with its anterior sphenoidal wall so as to reach the tumoral mass (Figure 2). Internal decompression was applied on the tumoral tissue, and its capsule was dissected totally away and removed from the peripheral tissues and dura without any complication. Hemostasis was achieved in the loge and spongostan ${ }^{\mathrm{TM}}$ and fatty graft taken from the abdominal subcutaneous layer were placed in situ. Subsequently, the layers were closed respecting the anatomical layers from inside to outside. During closure of the pediculated nasal tissue, tampons were packed inside nasal orifices to preserve anatomic integrity. The nasal incision was closed with hidden sutures. The nasal bone was fixed with cast and splint. The patient was extubated during the postoperative period without any complication. On the first postoperative day, the preexisting deficit was seen to have regressed and the cranial nerves were intact. Prophylactic antibiotherapy with ceftriaxone $(2 \mathrm{~g} / \mathrm{d})$, and analgesia with opioids and nonsteroidal medications were started. Nasal tampons were removed on the 3rd postoperative day, and the cast splint on the 7th day without any complication. She was discharged on the 8th postoperative day. In her first year follow-up, control cranial MRI revealed the tumor to be totally extirpated with a cosmetically good outcome (Figure 1B, Figure 3).

\section{DISCUSSION}

This type of tumor is localised in the sphenooccipital region in nearly $35 \%$ of the cases and frequently in the clivus, petrous apex, cavernosal sinus, foramen magnum and sphenoethmoidal regions (8). Two-thirds of cranial chordomas are seen in the clivus. They are primarily extradural. Most extradural chordomas arise from the clivus, and separate the dura from the bone along a larger border. 

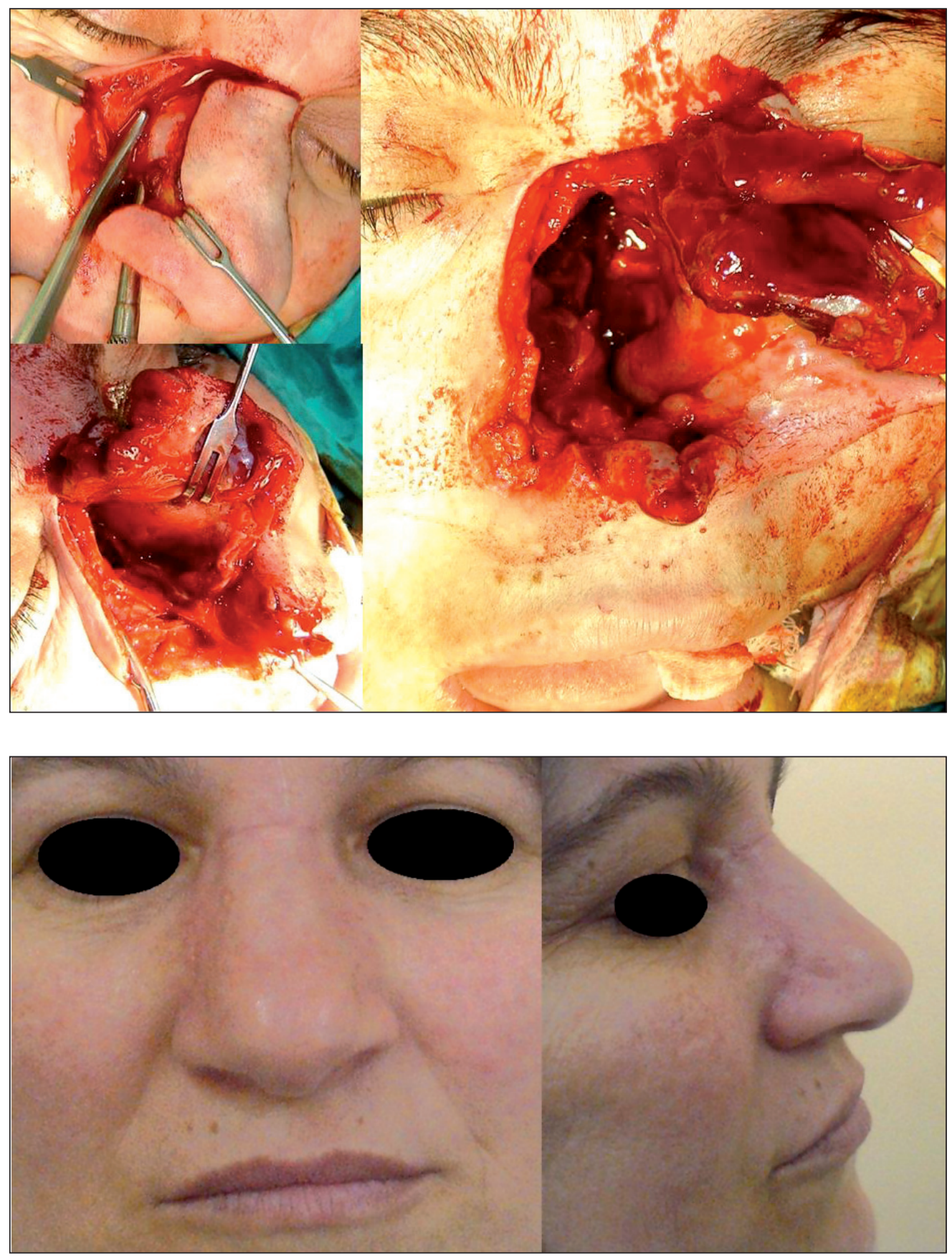

Figure 2: Peroperative nasal opening image. Upper left : Incision made on the right lateral nasal line beginning from glabella and extending inferiorly, and nasal osteotomy. Lower left: Nasal osteotomy was completed. Right: Image of a pedicled nose and the base of the sphenoidal sinus.

Figure 3: Postoperative 3. months: Postoperative patient's facial photos (with the permission of the patient) Abbreviations: magnetic resonance imaging (MRI); arterial blood flow (ABF); doppler ultrasonography (USG).
They could compress pons, medulla and the fourth ventricle. Radical resection of the chordomas of the basis cranii is the key factor for a longer survival and quality of life. High-dose postoperative radiotherapy is frequently recommended $(1,2,3)$. Surgical approaches to clival chordomas include frontal, temporal, and suboccipital craniotomies, petrosal and parapetrosal procedures, and combinations of nasal and oropharyngeal routes $(7,10)$. These approaches necessitate extensive cranial opening and significant retraction of the brain. Recently, the endoscopic transsphenoidal approach has been reported to treat clivus chordoma in the literature $(5,11)$.
An expanded endoscopic endonasal approach is reported to be at least equivalent to more extensive open approaches (5).The main problems in this approach are related to the hemorrhage control of intracranial vessels and to the closure of the dural and bony defects, with subsequent increased risk of postoperative cerebrospinal fluid leak.

Anterior transfacial approaches to the full clivus usually traverse the nasal cavity and its associated sinuses (4).

Lateral rhinotomy using the transfacial route provides a good exposure for midline tumors progressing along the 
rostocaudal axis. It is not possible to approach the lateral lesions of the carotis with this technique. However, resection of the middle and lower conchas or removal of the wall of the maxillary sinus might provide a larger exposure (1). This technique is a modification of the classical Weber-Ferguson incision. On the contrary, opening of the lips and lower eyelids is not required. Pedicled rhinotomy provides a shorter surgical corridor to the clivus by disarticulating and laterally rotating the nasal bone and cartilage away from the midface $(9,12)$. In our case, a large exposure was achieved through a lateral nasal incision in order to excise the tumor totally with acceptable cosmetic results, and successful outcomes were observed during the postoperative follow-up period with the surgical procedure applied.

Aggressive surgical treatment, however, has been associated with higher morbidity and mortality rates (6). Many chordomas of the clivus extend posteriorly, distend or traverse the clival dura, and invaginate the brainstem. The proximity of the tumor to the radiation-sensitive brainstem structures can limit the radiation dose that can be administered safely $(1,2)$. Choosing the right patient for this surgery is advantageous. Preference for radical surgery and protection of the patient from the complications of the combined surgery are the most important issues. The choice of the right approach should target total tumoral exposure without brain retraction, preservation of vital neural and vascular structures, precautions (eg. hemostasis) against potential complications stemming from location of the tumor, repair of the dura in case of accidental opening of dura, better physiological and cosmetic outcomes, and best curative effects of surgical and medical therapy. In the present case, the location of the tumor on the upper midclivus, its isolated midline position and sellar destruction secondary to its extension to sellar structures directed our preference of the approach.

In conclusion, the surgical treatment of clival chordomas is very difficult to manage. The transfacial pedicled rhinotomy approach is comfortable for upper and midclival tumors and postoperative results are better for properly chosen surgical candidates.

\section{REFERENCES}

1. Al-Mefty O, Borba LAB: Skull base chordomas: A management challenge J Neurosurg 86:182-189, 1997

2. Austin-Seymour M, Munzenrider J, Goitein M, Verhey L, Urie M, Gentry R: Fractionated proton radiation therapy of chordoma and low grade chondrosarcoma of the base of the skull. J Neurosurg 70: 13-17, 1989

3. Benk V, Liebsch NJ, Munzenrider JE, Efird J, McManus P, Suit H: Base of skull and cervical spine chordomas in children treated by high-dose irradiation. Int J Radiat Oncol Biol Phys 31:577-581, 1995

4. deFries HO, Deeb ZE, Hudkins CP: A transfacial approach to the nasal-paranasal cavities and anterior skull base. Arch Otolaryngol Head Neck Surg 114:766-769, 1988

5. Dehdashti AR, Karabatsou K, Ganna A, Witterick I, Gentili F: Expanded endoscopic endonasal aproach for treatment of clival chordomas: Early results of 12 patients. Neurosurgery 63(2): 299-307, 2008

6. Gay E, Sekhar L N, Rubinstein E, Wright D C, Chandranath Sen, Janecka I P: Chordomas and chondrosarcomas of the cranial base: Results and follow-up of 60 patients. Neurosurgery 36: 887-897, 1995

7. Harsh G, Ojemann R, Varvares M, Swearingen B, Cheney $M$, Joseph M: Pedicled rhinotomy for clival chordomas invaginating the brainstem, Neurosurg Focus 10 (3):1-6, 2001

8. Higinbotham NL, Phillips RF, Farr HW, Hustu OH: Chordoma. Thirty-five-year study at Memorial Hospital. Cancer 20:18411850, 1967

9. Joseph M: Pedicled rhinotomy for exposure of the clivus, in Schmidek HH, Sweet WH (eds): Operative Neurosurgical Techniques, 3th ed. Philadelphia: WB Saunders, 1995:469-475

10. Sekhar LN, Sen C, Snyderman CH: Anterior, anterolateral, and lateral approaches to extradural petroclival tumors, in Sekhar LN, Janecka IP eds: Surgery of Cranial Base Tumors. New York: Raven Press, 1993:157-224

11. Stippler M, Gardner PA, Snyderman CH, Carrau RL, Prevedello DM, Kassam AB: Endoscopic endonasal approach for clival chordomas. Neurosurgery. 64(2):268-77, 2009

12. Swearingen $B$, Joseph $M$, Cheney $M$, Ojemann RG: A modified transfacial approach to the clivus. Neurosurgery 36:101-105, 1995 